\title{
NERVE FIBRES IN ISOLATED SEGMENTS OF DOG ULNAR NERVES AFTER COMPLETE BRACHIAL PLEXOTOMY AND PERIAXILAR ARTERY SYMPATHECTOMY
}

\author{
Eros Abrantes Erhart * \\ CECIL J. REZZE **
}

We reported observation of nerve fibres of normal appearance in the distal segments of human nerves which had been completely transected for years (Erhart ${ }^{5}$ ). Experimentally we reproduced the phenomenon in dogs (Erhart and Erhart 6,7 ). Wide gaps between proximal and distal stumps were present in all instances. No nerve fibres could be found in the tissues between the stumps, nor were collateral sprouts observed to come off the proximal intact part of the nerve. It seemed, therefore, that those fibres of normal appearance must have arisen from a source other than the proximal stump of the severed nerve.

\section{MATERIAL AND METHODS}

Experiments were performed under general anesthesia in ten adult mongrel dogs. The ulnar nerve was chosen because it runs a long course in the fore limb without branching or engaging in intercommunications. The procedures were to be carried out in four stages using the right side. The following description corresponds to the standard scheme (fig. 1):

a) In the first stage, the nerve was divided in two places, just caudal to the branching of the caudal cutaneous antebrachial nerve, and just caudal to the elbow, and segments removed between double black cotton ligatures, as shown in fig. $1 \mathrm{~A}$. The intermediate and distal segments were left in place undisturbed by dissection. The excised segments were prepared histologically for controls.

b) More than a year later, the operative field was opened under anesthesia, and the ligatures identified. The extremities of the proximal, intermediate and distal segments were freed gently and excised with the tissues bridging the segments. All this material was prepared histologically by DeCastro silver impregnation, Masson, Mallory connective tissue, Pal-Weigert modified by Erhart for myelin sheaths, and $\mathrm{H} \& \mathrm{E}$ general methods. New ligatures were applied an the wound closed.

c) One month later, a right brachial plexotomy and periaxilar artery sympathectomy were performed. Were excised the ventral rami from $C_{4}$ to $T_{1}$, trunks and cords of the plexus till the level where arise the main nerves of the limb, the stumps of all components being ligated with white cotton threads. The periarterial sympathectomy severed 4 to $5 \mathrm{~cm}$ of the axilar artery. The wound was closed.

Departamento de Anatomia da Faculdade de Medicina da Universidade de São Paulo (Prof. O. Machado de Sousa): * Professor Assistente, Docente-Livre, Chefe da Secção de Neuranatomia; ** Professor Assistente. 
d) One month later, the operative field was again exposed under anesthesia and the wide gaps between the three segments of the ulnar nerve identified. The proximal, the intermediate and the distal segments were excised for histological study (fig. 1D), as well as segments of other transected nerves to be used for controls.

From the ten dogs subjected to the standard ulnar nerve operation, four were successfully submitted to the proposed scheme, with some peculiarity which will be considered later on. One died during the third operation. Three died from injuries incurred as the result of fighting in the kennel. The remaining two are still living in order to be submitted to the proposed scheme, being elapsed two or more years after the standard operation.

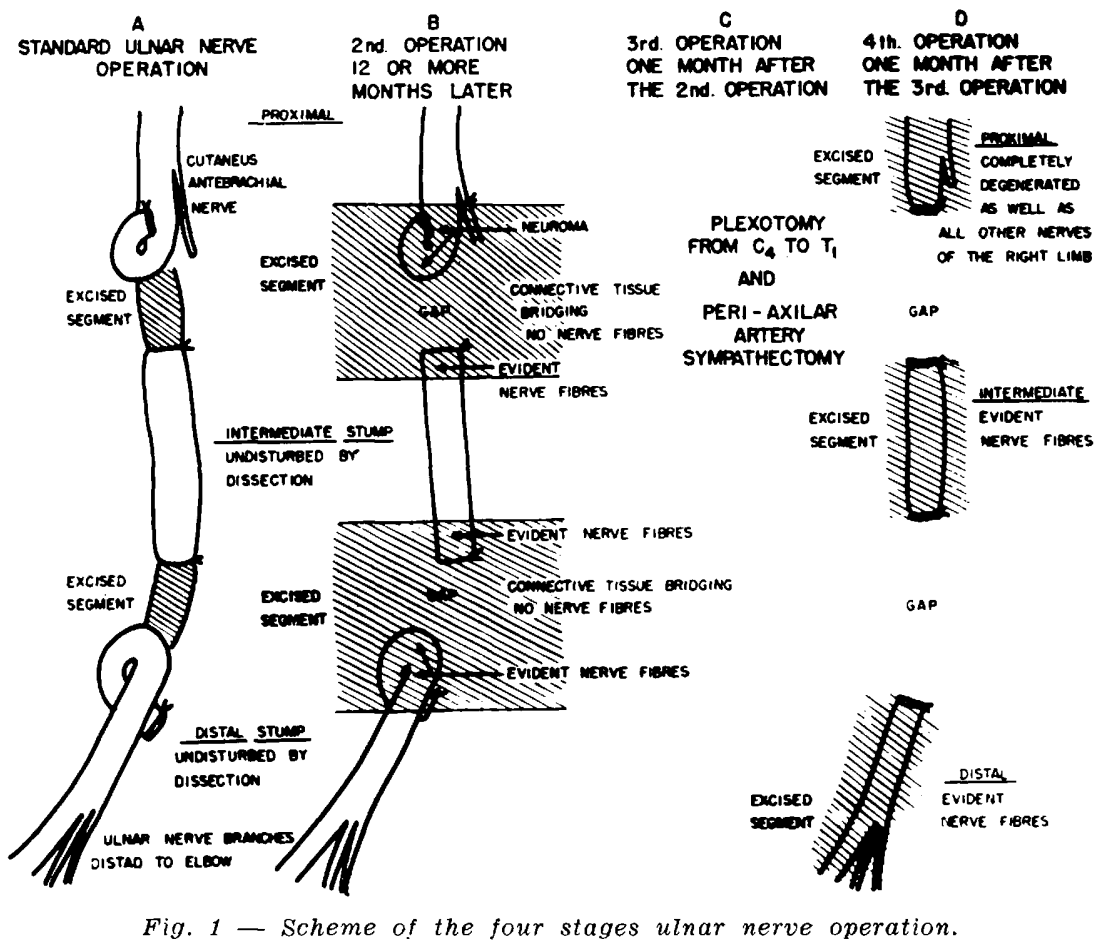

\section{RESULTS}

After the first operation all ten dogs showed complete motor and sensory loss in the territory supplied by the right ulnar nerve. It was evident the vicious pcsture due to the denervation of the $\mathrm{m}$. flexor carpi ulnaris.

While performing the second operation and the necroscopy of the three referred dogs which have died precociously, in all instances wide gaps separated completely the proximal, intermediate and distal segments of the ulnar nerve. No gross intercommunications with other nerves were evident in the surgical field.

When excising during this operation the proximal extremity of the distal stump, there was in some cases a discrect contraction of the $\mathrm{m}$. flexor carpi ulnaris.

The serial histological preparation longitudinally and cross-sectioned of the nerves submitted to the second operation revealed the following: a) Proximal stumps with neuroma, as expected; b) Numerous nerve fibres and nerve bundles (fig. 2A and $B$ ) in the excised extremities of the intermediate and distal segments; c) No 

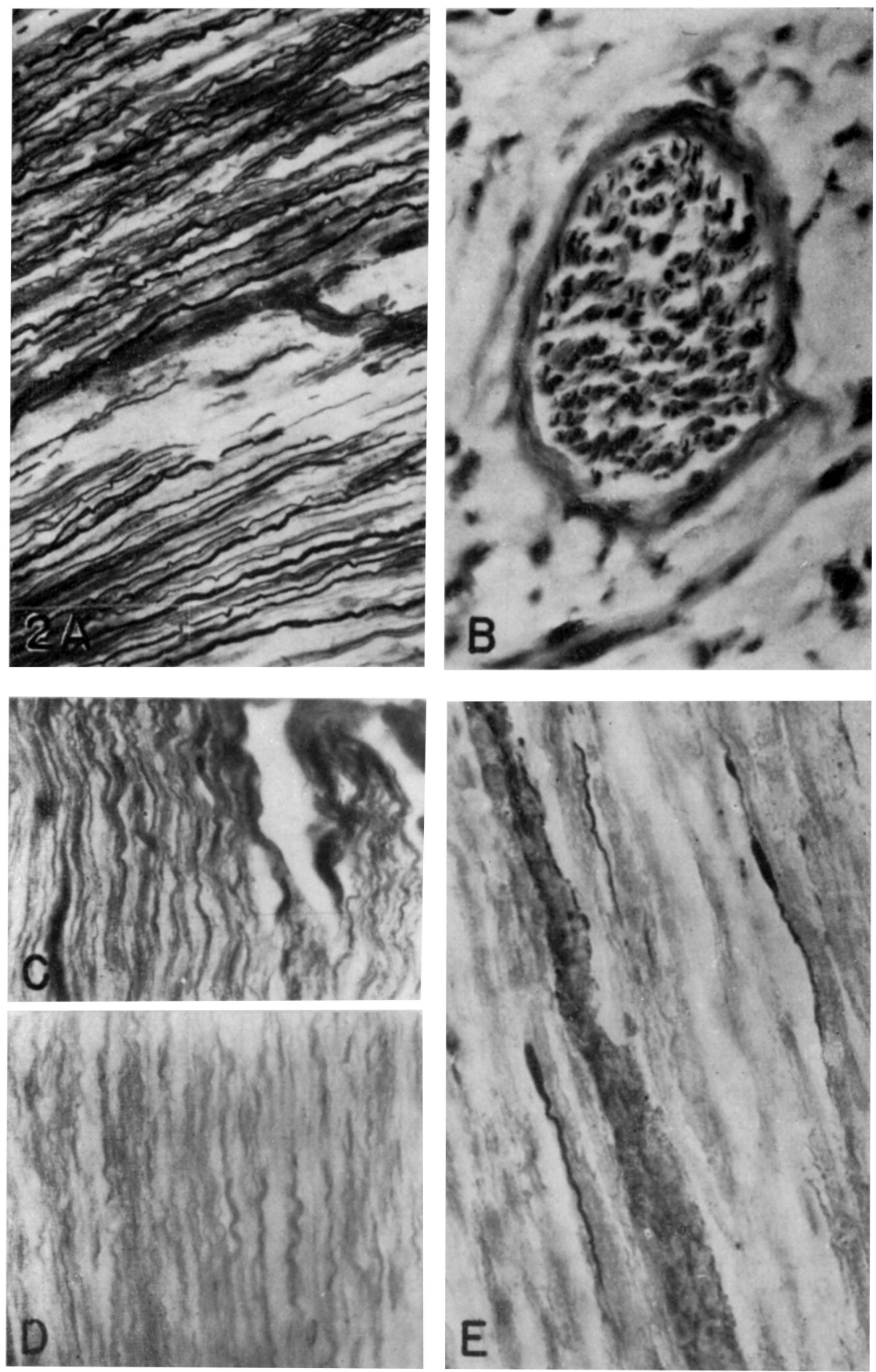
nerve fibres could be found penetrating the extremities of the intermediate and distal segments, nor in the tissues bridging the stumps; d) Neuroma-like structures in the extremities of the intermediate and distal stumps close to the site of section.

The histological preparation of the intermediate and distal segments of the dogs whtch have died respectively thirty-five, eighty and one hundred and sixty days after the first operation, showed all known characteristics of the Wallerian degeneration.

As consequence of the third operation - plexotomy and periarterial sympathectomy (fig. 1C) - the dogs showed complete motor and sensory loss of the whole right fore limb with a characteristic vicious posture, plus clinical signs of an effective periarterial sympathectomy.

Sympathectomy was not done in one of the dogs and, as referred before, one died during this operation. From this latter a thorough examination of the operative field was conducted. Wide gaps were separating the stumps and the histological serial preparation of the intermediate and distal ulnar nerve segments, which were left in place undisturbed by dissection, showed nerve fibres and nerve bundles.

The ulnar nerve material excised during the fourth operation (fig. 1D) revealed the following: a) Proximal stump completely degenerated because of the plexotomy; b) Nerve fibres and bundles in the intermediate and distal ulnar nerve stumps (fig. $2 \mathrm{C}$ and $\mathrm{D}$ ). Some fibres showed varicosities or fusiform swellings in one of the extremities or disposed along the axis-cylinder (fig. 2E), giving them a beaded appearance; c) No nerve fibres could be found penetrating the extremities of the intermediate and distal ulnar nerve segments.

Median, radial and musculo-cutaneous nerve segments excsised for control showed complete Wallerian degeneration.

\section{DISCUSSION}

Our experimental findings of nerve fibres with normal appearance in the distal and intermediate segments of nerves completely separeted from the proximal stumps for more than six months, discussed by our former papers, were again confirmed, leading us definetely to a different conclusion of what is generally accepted by most of the modern authors.

J.B. Campell from the Neurosurgical Laboratory, New York University School of Medicine confirming our findings wrote the following in two letters addressed to us: April 1962 "In the distal stump, capped with Millipore in order to preclude access of axons, there were plenty axons". April 1963 "Microscopic study with silver impregnation and myelin stains tend to confirm all the findings in your paper". Discussing his own findings he suggested: "I provisionally conclude that these axons must have their origin in the innervation of the blood vessels of the distal stump. Bearing this in mind, I deduced that they have spread into the Schwann tubules left vacant by the preceding transection. I do not know whether my conclusions agrees with yours, but the observation definitely substantiates what you have seen".

Fig. 2 - Photomicrographs of $8 \mu$ sections of dog ulnar nerves submitted to the four stages operation. De Castro silver simpregnation $(\times 700)$. A and B. Nerve fibres in the intermediate nerve segment excised by the second operation (dog number $X I I)$. C and $\mathrm{D}$. Nerve fibres in the intermediate and distal nerve segments excised by the fourth operation (dog number $X$ ). E. Nerve fibres with turgescences (neurogenic buddings) in the intermediate nerve segment excised by the fourth operation (dog number IV). 
This hypothesis was also previously considered by us in another paper ${ }^{5}$, but these new results seem to exclude the possibility of reinnervation of the intermediate and distal segments being done by ingrowing sprouts comming from other nerves or from "nervi-vasorum".

Lee Ching-Yuen 11 studying the Wallerian degeneration on the electron microscope states: "From the seventh day onward after resectioning sciatic nerves (one to three centimeters) of rats and rabbits, all the axoplasmic organells gradually disappeared from the axon of myelinated fibres. On the twenty-first day all the organelles were still seen in the axons of unmyelinated fibres but on the twenty-eigth day only dense particles and the endoplasmatic reticulum were found. On the thirty-fifth day no axonal remants were present".

How can one explain than the presence of nerve fibres with normal appearance in the intermediate and distal stumps of long-time transected and reoperated uinar nerve, thirty days after a complete plexo-and sympathectomy and sixty days after the excision of the stumps extremities (stage B operation)?

The somatic and sympathetic fibres of the main nerve trunks were transected and excised by the plexotomy, an the sympathetic fibres which run toghether with the arterial branches of the axilar artery were mostly excised by the periarterial sympathectomy. We know that other nerve pathways through arterial anastomoses nets and muscles could be considered, but why do we find nerve fibres with normal appearance only in the intermediate and distal ulnar nerve previously operated segments? If those repopulating nerve fibres came together with vascular branches, or through some other way, they should be seen also in other nerves. Or the long-time severed nerve segments present different living conditions! We know there are the neurilemma bands waiting for the ingrowing of new nerve-fibres. But why those nerve fibres begin to appear, and can be found as stated in previous paper, only six months after the nerve transection, if the distal segment is kept in its surrounding connective tissue bed! Nerve fibre growing is not so slow to take six months to reach the upper third of the forearm. Before the sixth month the nerve stumps were always completely degenerated.

If these axis-cylinders found in the intermediate and distal long-time severed ulnar nerve segments were ingrowed nerve-fibres, why they did not degenerate when the stumps were cut, as we did in our four stages uInar nerve operation.

The axis-cylinders found in the distal and intermediate ulnar nerve segments of these dogs were always inside the pattern nerve fascicles, characteristic to each level of the ulnar nerve. They were never close to the vasa-nervorum nor were disposed close to the periphery of a nerve fascicle, in relation to the peri- or epineurum. They were always disposed as "lost" among the neurilemma bands of proliferated Schwann cells. They were more numerous in the smaller fascicles and in the most central part of the nerve when considering the nerve in cross-section; probably because the center of 
the nerve, as a whole, is the less affected part of the structure while manipulating the nerve segments during the operations.

In serial longitudinal and cross-sections we have followed these axiscylinders but, from where they came from, or their origin, we were not able to find. We could never, as said before, find nerve-cells along such nerve segments.

Gamble and Eames ${ }^{9}$ describing electron microscopy pictures of degenerated human deep ulnar nerve avulsed from the cord some fifteen months previously, wrote the following: "Most of these processes are believed to belong to Schwann cells organized as bands of Büngner but a few have the appearance of and may be surviving or regenerating axons".

We hope that these authors interpretation is correct because such electron microscopy pictures would confirm once more our findings.

With respect to the fusiform swellings found in the extremities or along the axis-cylinders of the intermediate and distal long-time severed ulnar nerve segments, they seem to be the same structure described many years ago by Cajal ${ }^{3}$ and studied under the electron microscope by Estable and his group ${ }^{8}$. These latter authors state: "It is an experienced fact that besides the mentioned terminal growing bud, formative turgescences along the nerve fibre exist, which can be, in turn, the place of neurogenic budding. This fact would lead to the inference that the nerve fibre has all along its segments the potencial property of regeneration or, in a wider sense, of creating all the structures that normally constitute them". "From a general point of view regeneration means: the morphological building of new nerve fibres (proliferation) and restitution of nerve functions".

In recent papers Blümcke ${ }^{1}$, Blümcke and Niedorf ${ }^{2}$, Knoche and Blümcke ${ }^{10}$ performing careful histochemical and electron microscopy examinations of normal and regenerating peripheral nerve fibres, consider also these fusiform swellings (Wachstumsendkolben - growing end bulbs) as characteristic of regenerating nerve fibres.

It must be emphasized that we found axis-cylinders with these "neurogenic buddings" in the isolated stumps of the ulnar nerve of dogs which were submitted after the second nerve transections (stage B operation), to a plexoand sympathectomy.

How can one explain the presence of axis-cylinders with growing buds without the trophic action of a cell-body?

Recently Courtey ${ }^{4}$ studying in tissue culture the regeneration of isolated and transected nerve fibres of chick embryos under the phase microscope states: "Le bout distal se présente comme une portion de neurite isolé du péricaryon, avec une arborisation terminale à chaque extrémité, douée chacune d'une activité propre qui permet l'allongement de la fibre synchroniquement en directions distale et proximale".

His findings were on culture of embryonic nervous tissue which growing properties are quite different from those of the completely developed nerve fibres. 
Could we consider homologous in behaviour, Courtey's distal segment and our intermediate and distal ulnar nerve segments kept practically undisturbed on their surroundings connective tissue bed, in the "millieu" of Cajal?

Courtey described in each extremity of the distal segment "une arborisation terminale"; this structure would be the primordia of the growing bud?

More recently, Levi-Montalcini ${ }^{12}$ suggests that the protein "nerve growth factor" (NGF) which was isolated from some mouse sarcomas, snake venom and mouse salivary glands, which is a normal constituent of the sympathetic cells, and is also present in the blood and body fluids of a variety of vertebrates, man included, may provide new leads to understanding of some neurogenetic processes. Moreover, she states that granuloma tissue, experimentally produced in a variety of mammals, releases NGF and suggests, furthermore, that there is reason to believe that each nerve cell type might be receptive to only one specific factor.

We know that after nerve severance there is an intense proliferation of Schwann cells and epi- peri- and endoneural reactions. Would these repair processes release some "nerve growth factor" which would be perhaps one of the keys to lead us to some explanation of our findings?

Another still open question is the explanation of the neuroma-like structures generally found in the extremities of long-time severed intermediate and distal nerve segments. This problem will be considered in another paper.

More concrete data about our findings are naturally necessary and the experiments are going on. Even so, as stated in previous paper, the practical results obtained up to now in more than one hundred and fifty patients allows us to go on recommending strongly, based on our observations, that proper nerve suture or neurolisys of long-time severed nerves by accident are worth while even after delays of many years.

\section{SUMMARY}

Experiments were performed in adult dogs in order to study our reported observation of normal nerve fibres in the intermediate and distal segments of nerves completely separated from the proximal stump for more than six months.

The results obtained confirmed once more our previous observation: there are normal nerve fibres and nerve bundles repopulating the pattern fascicles of the completely separated intermediate and distal segments of the ulnar nerve, although all other nerves of the operated limb, including the proximal stump of the ulnar, show a typical Wallerian degeneration. It seems, therefore, that these fibres of normal appearance must have arisen from a source other than the proximal ulnar nerve stump, neighbour nerves or "Nervivasorum".

More concrete data about these findings are naturally necessary and our experiments are going on. Even so, as stated before, the practical results obtained up to now in more than one hundred and fifty patients allows us to 
go on recommending strongly, based on our observations, that proper nerve suture or neurolisys of long-time severed nerves by accident are worth while even after delays of many years.

\section{RESUMO}

Prosseguindo estudos anteriores que demonstraram a existência de fibras integras no segmento distal de nervos com mais de seis meses de seç̧ão completa, novas experiências foram efetuadas em cães, desta feita sendo utilizado o nervo ulnar, por causa de suas caracteristicas morfo-funcionais e topográficas que se enquadravam perfeitamente aos nossos propósitos.

A experimentação foi desenvolvida obedecendo a esquematização representada na fig. 1 . Os resultados obtidos confirmaram nossos achados anteriores, visto que, mesmo após plexotomia braquial total e simpatectomia periarterial da artéria axilar, continuaram evidentes numerosas fibras nervosas de aspecto normal nos segmentos intermédios e distal do nervo ulnar mantidos em seus leitos conetivos naturais, mas completamente separados entre si e do côto proximal. Essas fibras nervosas, em face da experimentação efetuada, parecem não ser provenientes do côto proximal do nervo ulnar, nem de intercomunicações com nervos vizinhos, nem tãopouco de "nervi-vasorum". Há indícios, no entanto, que possivelmente tenham se originado à custa de elementos constituintes de fibras "degeneradas", sob regência conjugada das células de Schwann e do meio ambiente natural. Os trabalhos prosseguem nesse sentido em busca de dados mais concretos. Todavia, desejamos ressaltar que os resultados práticos obtidos até o momento em mais de cento e cinqüenta pacientes, segundo informações de vários colegas que têm dado crédito às nossas pesquisas, vêm demonstrar que muito se poderá fazer em prol da reabilitação de inválidos, através de reconstruções e recuperação funcional de nervos com lesões antigas que infelizmente vinham sendo considerados como irreversíveis e irreparáveis.

\section{REFERENCES}

1. BLUMCKE, S. - Untersuchungen über die Acetylcholinesterase-Aktivität in Wachstumsendkolben regenerierender peripherer Nervenfasern. Acta Neuropathologica 4:58-64, 1964. 2. BLUMBCKE, S. \& NIEDORF, H. R. - Elektronenoptische Untersuchungen über die Feinstruktur der "Neurofilamente" in der normalen und regenerierenden peripheren Nervenfaser. Beitr. Anat., 130:133-157, 1964. 3. CAJAL, S. RAMON y - Degeneration and Regeneration of the Nervous System. Translated and Edit. by Raoul M. May. Oxford Univ. Press. London, 1928. 4. COURTEY, B. Observation en contraste de phase de la régéneration "per primam intentionem" des fibres nerveuses en culture chez l'embriyon de poulet. Comptes Rendus de l'Ass. Anat., 117-458-473, 1963. 5. ERHART, E. A. - Normal nerve-fibres in the distal segment of nerves completely separated from the proximal stump for more than six months. Arq. Neuro-Psiquiat. (São Paulo) 20:289-306, 1962. 6. ERHART, E. A. \& ERHART, M. B. - Normal axis-cylinders in the distal segment of nerves completely separated from the proximal stump for up to 24 years. Presented before the VII International Congress of Anatomists, New York, April 1960 . Anat. Rec., 136:189, 1960. 7. ERHART, M. B. \& ERHART, E. A. - Sôbre o comportamento das fibras nervosas no côto distal de nervo fibular de Canis familiaris após transec- 
cão total. Presented before the III Meeting of the Soc. Bras. de Anatomia, Pôrto Alegre, Oct. 1958. Folia Clinica et Biologica (Sāo Paulo) 28:98-100, 1958/59. 8. ESTABLE, C.; ACOSTA-FERREIRA, W. \& SOTELLO, J. R. - An electron microscope study of the regenerating nerve fibres. Zeit. f. Zellforschung 46:387-399, 1957.9. GAMBLE, N. J. \& EAMES, R. A. - Electron microscopy of the connective tissues of normal and degenerated human peripheral nerves. J. Anat., 98:175, 1964. 10. KNOCHE, H. \& BLUMCKE, S. - Lichtmikroskopische Beobachtungen über frühe Regenerationsstadien peripherer Nerven. Zeit. f. Mikros. Anat. Forschung 69:248-278, 1962. 11. LEE CHING-YUEN, J, - Electron microscopy of Wallerian degeneration. J. Comp. Neurol., 120:65-80, 1963. 12. LEVI-MONTALCINI, R. - Growth control of nerve cells by a protein factor and its antiserum. Science 143:105-110, 1964.

Departamento de Anatomia. Faculdade de Medicina da Universidade de São Paulo - Caixa Postal 2921 - São Paulo, Brasil. 